\title{
Leptin interferes with 3',5'-Cyclic Adenosine Monophosphate (cAMP) signaling to inhibit steroidogenesis in human granulosa cells Qing Lin ${ }^{\dagger 1,2}$, Song Ling Poon ${ }^{\dagger 1}$, Junling Chen ${ }^{1}$, Linan Cheng ${ }^{3}$, Basil HoYuen ${ }^{1}$ and Peter CK Leung*1
}

Address: ${ }^{1}$ Department of Obstetrics and Gynecology, Child and Family Research Institute, University of British Columbia, Vancouver, British Columbia, V6H 3V, Canada, ${ }^{2}$ Department of Obstetrics and Gynecology, Beijing Friendship Hospital-Affiliate of Capital University of Medical Sciences, Beijing, PR China and ${ }^{3}$ School of Medicine, Shanghai Jiao Tong University, Shanghai, 200030, PR China

Email: Qing Lin - qing.lin1008@gmail.com; Song Ling Poon - songlp@yahoo.com; Junling Chen - chen_junling@hotmail.com; Linan Cheng - linanc2@yahoo.com; Basil HoYuen - bhoyuen@interchange.ubc.ca; Peter CK Leung* - peleung@interchange.ubc.ca

* Corresponding author †Equal contributors

Published: 22 October 2009

Reproductive Biology and Endocrinology 2009, 7:115
Received: 12 May 2009

Accepted: 22 October 2009

This article is available from: http://www.rbej.com/content/7/I/II5

(c) 2009 Lin et al; licensee BioMed Central Ltd.

This is an Open Access article distributed under the terms of the Creative Commons Attribution License (http://creativecommons.org/licenses/by/2.0), which permits unrestricted use, distribution, and reproduction in any medium, provided the original work is properly cited.

\begin{abstract}
Background: Obesity has been linked to an increased risk of female infertility. Leptin, an adipocytokine which is elevated during obesity, may influence gonadal function through modulating steroidogenesis in granulosa cells.
\end{abstract}

Methods: The effect of leptin on progesterone production in simian virus 40 immortalized granulosa (SVOG) cells was examined by Enzyme linked immunosorbent assay (ELISA). The effect of leptin on the expression of the steroidogenic enzymes (StAR, P450scc, 3betaHSD) in SVOG cells was examined by real-time PCR and Western blotting. The mRNA expression of leptin receptor isoforms in SVOG cells were examined by using PCR. SVOG cells were co-treated with leptin and specific pharmacological inhibitors to identify the signaling pathways involved in leptin-reduced progesterone production. Silencing RNA against leptin receptor was used to determine that the inhibition of leptin on cAMP-induced steroidogenesis acts in a leptin receptor-dependent manner.

Results and Conclusion: In the present study, we investigated the cellular mechanisms underlying leptin-regulated steroidogenesis in human granulosa cells. We show that leptin inhibits 8-bromo cAMP-stimulated progesterone production in a concentration-dependent manner. Furthermore, we show that leptin inhibits expression of the CAMP-stimulated steroidogenic acute regulatory (StAR) protein, the rate limiting de novo protein in progesterone synthesis. Leptin induces the activation of ERK I/2, p38 and JNK but only the ERK I/2 (PD98059) and p38 (SB203580) inhibitors attenuate the leptin-induced inhibition of CAMP-stimulated StAR protein expression and progesterone production. These data suggest that the leptin-induced MAPK signal transduction pathway interferes with cAMP/PKA-stimulated steroidogenesis in human granulosa cells. Moreover, siRNA mediated knock-down of the endogenous leptin receptor attenuates the effect of leptin on CAMP-induced StAR protein expression and progesterone production, suggesting that the effect of leptin on steroidogenesis in granulosa cells is receptor dependent. In summary, leptin acts through the MAPK pathway to downregulate CAMP-induced StAR protein expression and progesterone production in immortalized human granulosa cells. These results suggest a possible mechanism by which gonadal steroidogenesis could be suppressed in obese women. 


\section{Background}

The major function of the female gonad is to differentiate and release mature oocytes for fertilization and successful propagation of the species. The follicular maturation, ovulation and corpus luteum function of mammalian ovaries is regulated by the interaction between gonadotropin releasing hormone, gonadotropins, ovarian sex steroids and a variety of peptide hormones [1]. Dysfunction in the biosynthesis of sex steroid hormones could impair normal ovarian function or even cause infertility.

Leptin, a key hormone in energy homeostasis and neuroendocrine function, has a permissive role in initiating puberty and is crucial in the pathogenesis of reproductive dysfunction in several disease states of energy imbalance [2]. In obesity, there is an expansion of the adipose tissue with increased leptin production [3]. Accumulating evidence suggests that increased leptin levels contribute to the pathogenesis of reproductive abnormalities including infertility, polycystic ovary syndrome (PCOS), anovulation, disruption of the menstrual cycle, hyperinsulinemia and many other conditions [4-6].

Recent studies that have identified expression of the leptin receptor in several peripheral tissues (eg. ovary, testis and adrenal gland) strongly suggest that leptin may have a direct effect on downstream endocrine targets of the reproductive axis $[7,8]$. In vitro studies conducted on thecal and granulosa cells have shown that leptin has negative effects on ovarian steroid output in rodent, bovine and human models. In particular, it has been found that: 1) Leptin antagonizes insulin action in human granulosa cells and thereby inhibits their gonadotropin-stimulated progesterone production [9]; 2) Leptin stimulates the release of proinflamatory cytokines and prostaglandins in human placenta [4]; 3) High serum and follicular fluid leptin may account for decreased fertilization, implantation and pregnancy rates of IVF in PCOS women [10]. Conditions with abnormally elevated leptin concentrations and impaired ovarian function may be due to disturbed steroidogenesis. However, the mechanisms by which leptin modulates steroidogenesis in the ovary remain elusive.

In the present study, we investigated the underlying mechanisms through which leptin modulates steroidogenesis in human granulosa cells. We found that treatment of immortalized granulosa cells with increasing doses of leptin inhibited 8-bromo cAMP-induced steroidogenesis with downregulation of the de novo produced steroidogenic acute regulatory (StAR) protein. In addition, we demonstrated that CAMP-regulated steroidogenic enzymes and progesterone production could be inhibited by leptin via the MAPK pathway.

\section{Methods \\ Cell culture and chemicals}

Studies of human ovarian granulosa cells have been limited by the small numbers and short life span in culture of cells currently obtained from clinical material. Using SV40 large T antigen, we have reproducibly immortalized freshly explanted human granulosa cells obtained through an in vitro fertilization program. The use of immortalized granulosa cells for this study was approved by the University of British Columbia Research Ethics Board. This cell line was shown to posses the same steroidogenic capabilities as primary human granulosa cells [11]. Cells are maintained in growth medium (M199:MCDB 105 (Sigma-Aldrich Corp., St. Louis, MO) containing $10 \%(\mathrm{v} / \mathrm{v})$ fetal bovine serum (FBS; Hyclone Laborataries Inc., Logan, UT), 100 units/mL penicillin, $100 \mu \mathrm{g} / \mathrm{mL}$ streptomycin (Sigma) under a humidified atmosphere of $5 \% \mathrm{CO}_{2}$ at $37^{\circ} \mathrm{C}$ and changed every 3 days. For each experiment, $2 \times 10^{5} \mathrm{immortalized} \mathrm{granulosa}$ cells were incubated in serum free medium for $4 \mathrm{~h}$ prior to treatment. Human recombinant leptin, 8-bromo cAMP, and SB203580 were purchased from Sigma. PD98059 and SP600125 were purchased from Calbiochem (San Diego, CA).

\section{RNA extraction and semiquantitave PCR}

Total RNA was extracted with Trizol reagent (Invitrogen Inc., Burlington, ON, Canada) according to the manufacturer's instructions. Reverse transcription was performed in a mixture containing $5 \mu \mathrm{M}$ random hexamer, $200 \mu \mathrm{M}$ dNTP, $2 \mathrm{U} / \mu \mathrm{l}$ MMLV trasnscriptase (Promega, Madison, WI) and $1 \mu \mathrm{g}$ RNA with the corresponding buffer at $42^{\circ} \mathrm{C}$ for $90 \mathrm{~min}$ followed by $85^{\circ} \mathrm{C}$ for $10 \mathrm{~min}$. The cDNA was further amplified by specific primer pairs, including forward long-form leptin receptor (OBRb) (5'-CCA GAA ACG TTT GAG CAT CT-3') and reverse OBRb (5'-CAA AAG CAC ACC ACT CTC TC-3'), forward short-form leptin receptor (OBRa) (5'-GAA GGA GTG GGA AAA CCA AAG-3') and reverse OBRa (5'-CCA CCA TAT GTT AAC TCT CAG-3'), forward GAPDH (5'-TCC CAT CAC CAT CTT CCA-3') and reverse GAPDH (5'-CAT CAC GCC ACA GTT TCC-3').

\section{Real-time PCR}

The primers used for SYBR Green real-time RT-PCR were designed using the Primer Express Software v2.0 (Applied Biosystems, Foster City, CA). The specific primer pairs used are forward StAR (5'-AAACTTACGTGGCTACTCAGCATC-3') and reverse StAR (5'-GACCTGGTTGATGATGCTCTTG-3'), forward P450scc (5'CAGGAGGGGTGGACACGAC-3') and reverse P450scc (5'-AGGTTGCGTGCCATCTCATAC-3'), forward 3 $\beta$-HSD (5'-GCCTTCAGACCAGAATTGAGAGA-3') and reverse $3 \beta$ HSD (5'-TCCTTCAAGTACAGTCAGCTTGGT-3'), forward GAPDH (5'-ATGGAAATCCCATCACCATCTT-3') and 
reverse GAPDH (5'-CGCCCCACTTGATTTTGG-3'). Realtime PCR was performed using the ABI prism 7000 Sequence 10 Detection System (Applied Biosystems) equipped with a 96-well optical reaction plate. The reactions were set up with 16.5 $\mu$ l SYBRR Green PCR Master Mix (Applied Biosystems). All real-time experiments were run in triplicate and a mean value was used for the determination of mRNA levels. Negative controls, containing water instead of sample cDNA, were used in each experiment. Relative quantification of the mRNA levels for StAR, P450scc and 3 3 -HSD2 in ovarian cancer cells was performed using the comparative CT method with GAPDH as an internal standard and with the formula $2^{-\Delta \Delta \mathrm{Ct}}$.

\section{Enzyme-Linked Immunosorbent Assay (ELISA)}

Immunoplates were pre-coated with IgG (Calbiochem) and nonspecific binding sites were blocked with $0.1 \%(\mathrm{w} /$ v) BSA buffer. IgG binds to the Fc fragment of the progesterone antibody while the Fab fragment is competitively bound by both biotinylated progesterone (EastCoast Bio, Inc. North Berwick, ME) and progesterone in the samples. The biotinylated progesterone interacts with streptavidinhorseradish peroxidase (SA-HRP) (EastCoast Bio), which catalyzes the substrate solution composed of 3,3',5,5'tetramethylbenzidine (TMB) (Dojindo Inc., Gaithersburg, $\mathrm{MD}$ ), to produce a blue-colored solution. The enzymesubstrate reaction is stopped by the addition of sulphuric acid $\left(\mathrm{H}_{2} \mathrm{SO}_{4}\right)$ and the solution turns yellow. The intensity of the yellow color is directly proportional to the amount of biotinylated peptide-SA-HRP complex but inversely proportional to the amount of the progesterone in the samples. A standard curve of progesterone with known concentrations was established accordingly, and the progesterone concentrations in the samples were determined by extrapolation to this standard curve. The intra- and inter-assay $\mathrm{CV}$ of the progesterone assay were 5.6 and $10.2 \%$ respectively.

\section{Western blotting}

The cells were washed twice with ice-cold PBS and lysed in RIPA buffer (150 mM NaCl, $50 \mathrm{mM}$ Tris-base (pH 7.5), $1 \%(\mathrm{v} / \mathrm{v})$ Nonidet P-40, 0.5\% (w/v) sodium deoxycholate, and $0.1 \%(\mathrm{v} / \mathrm{v})$ SDS). Twenty micrograms of total protein were run on $12 \%$ SDS-PAGE gels and electrotransferred to a nitrocellulose membrane (Biorad laboratories, Hercules, CA). The membrane was immunoblotted using specific primary antibodies (StAR, P450scc, 3 $\beta$-HSD and $\beta$ actin: Santa Cruz Biotechnology Inc., Santa Cruz, CA; ERK, phosphorylated ERK, JNK, phosphorylated JNK and p38: Cell Signaling Technology Inc., Danvers, MA; phosphorylated p38: Biosource, Invitrogen) at $4{ }^{\circ} \mathrm{C}$ overnight. After washing, the membranes were incubated with horseradish peroxidase-conjugated secondary antibody for $1 \mathrm{~h}$, and visualized using the ECL system (GE Healthcare BioScience, Piscataway NJ).

\section{Statistical analysis}

ELISA and real-time PCR normalized data are represented as mean \pm S.E.M. of three independent experiments. Western blot normalized data are represented as mean \pm S.D. of three independent experiments. Statistically significant differences between treatments and controls were determined by either two-way ANOVA followed by Bonferroni test (Figure 1 and Figure 2) or one-way ANOVA followed by Tukey test (Figure 3, 4, 5). Statistical significance was set at $P<0.05$.

\section{Results}

\section{Leptin attenuates the 8-bromo cAMP-stimulated} progesterone production in human granulosa cells

The gonadotropin-stimulated progesterone production in granulosa and luteal cell is critical for normal uterine function, establishment and maintenance of pregnancy, and mammary gland development $[1,12]$. To gain insight into the impact of leptin on gonadotropin-stimulated steroidogenesis, we co-treated 8-bromo cAMP with increasing concentration of leptin $(10 \mathrm{ng} / \mathrm{ml}, 100 \mathrm{ng} / \mathrm{ml}$, $1000 \mathrm{ng} / \mathrm{ml}$ ) for $24 \mathrm{~h}$ in immortalized human granulosa cells. Results showed that leptin inhibited the 8-bromo cAMP-stimulated progesterone production in a concentration-dependant manner, suggesting that leptin interferes with gonadotropin-stimulated progesterone production in these cells (Figure 1).

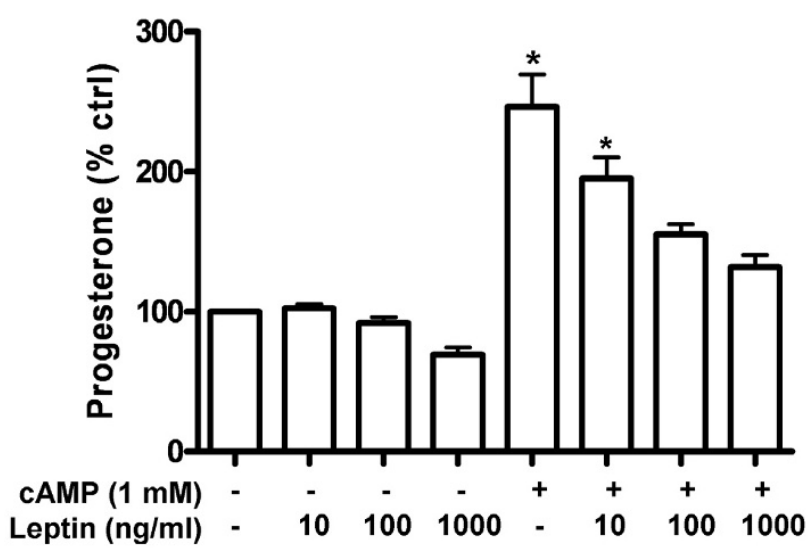

Figure I

Leptin inhibited 8-bromo CAMP-stimulated progesterone production in human granulosa cells. Cells were treated with increasing concentrations of leptin ( $10 \mathrm{ng} /$ $\mathrm{ml}-1000 \mathrm{ng} / \mathrm{ml})$ in the presence or absence of I mM 8bromo cAMP for $24 \mathrm{~h}$. Media were collected and assayed for progesterone production by ELISA. Each data point in the figure represents the mean \pm SEM of three independent experiments. * above the column indicates that those groups differ significantly from untreated control $(P<0.05)$; (ctrl $=$ control). 
A

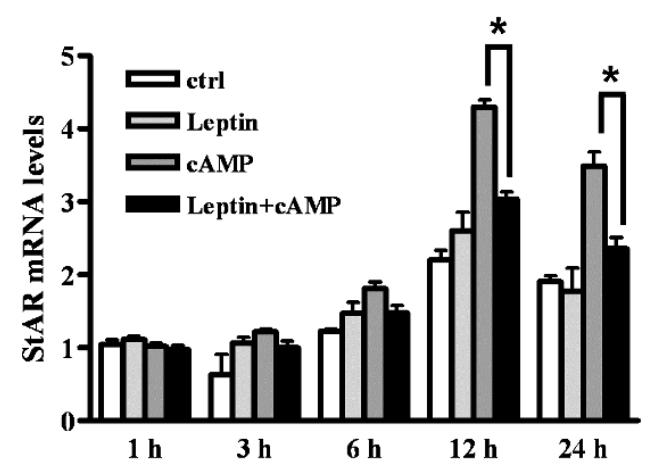

B

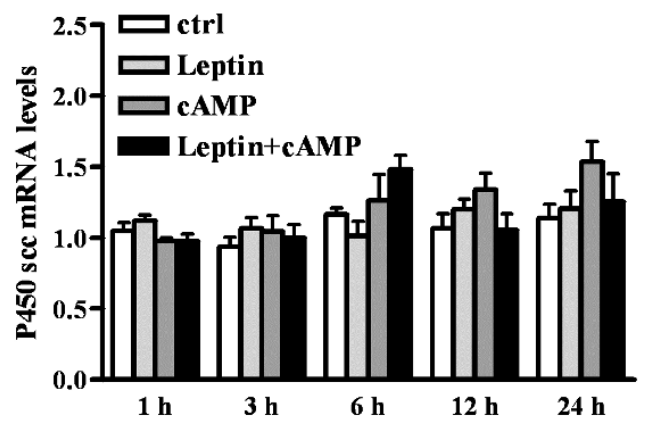

C

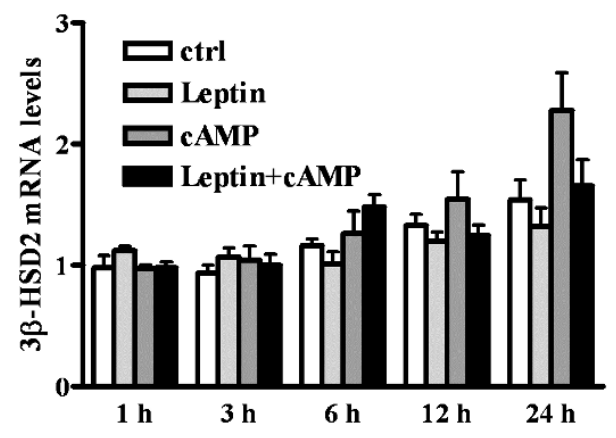

D

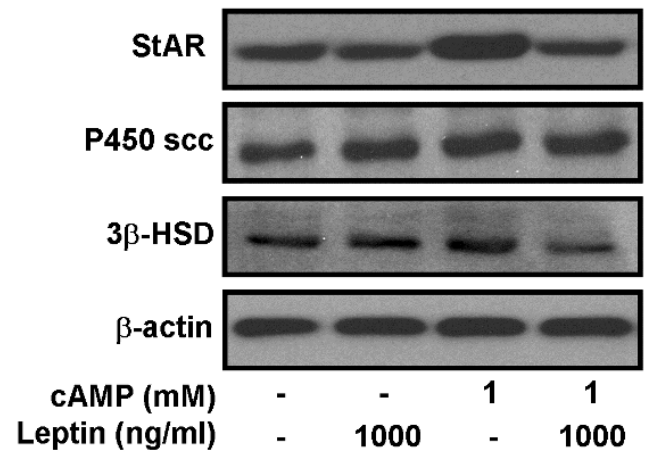

Figure 2

Leptin inhibited 8-bromo cAMP-stimulated StAR mRNA and protein expression. Cells were treated with leptin $(1000 \mathrm{ng} / \mathrm{ml})$ in the presence or absence of 8-bromo cAMP (I mM) for different time scale $(I, 3,6,12,24 \mathrm{~h})$ and total RNA was analyzed with real time RT-PCR to measure the temporal change of StAR mRNA (A), P450scc mRNA (B) and 3 $\beta$-HSD mRNA (C) levels with GAPDH as internal standard. Cell lysates from cotreatment of leptin with 8-bromo cAMP for $24 \mathrm{~h}$ was subjected to Western blot analysis to monitor the protein levels of StAR, P450scc and 3 $\beta-H S D(D)$. The blots are a Western blotting representative data from three independent experiments. Each data point in the figure represents the mean \pm SEM of three independent experiments. * above the bars in "A" indicate that cotreatment of leptin with cAMP group significantly differ from cAMP treated group in the particular time scale $(P<0.05)$. (ctrl $=$ control).

Leptin inhibits the 8-bromo cAMP-induced StAR mRNA and protein induction in granulosa cells

The regulation of StAR, P450scc enzyme and 3 $\beta$-HSD is crucial for regulating steroid hormone production in steroidogenic cells $[13,14]$. Using real-time PCR, we monitored the effect of leptin on these steroidogenic enzymes. Results showed that leptin inhibited the transcriptional mRNA level of StAR (Figure 2A), but not P450scc (Figure $2 \mathrm{~B}$ ) or $3 \beta$-HSD (Figure $2 \mathrm{C}$ ), in a temporally-defined manner. In concordance with the mRNA regulation, the protein level of StAR induced by 8-bromo cAMP is significantly inhibited by the administration of leptin after $24 \mathrm{~h}$ of treatment (Figure 2D).
Activation of ERKI/2 and $p 38$ are involved in the leptin regulated 8-bromo cAMP-stimulated StAR protein expression and progesterone production

As we have previously shown, immortalized human granulosa cells only expressed the short form leptin receptor (Ob-Ra) (Figure 3A) [15]. It is documented that the MAPK pathway is the dominant signaling pathway downstream of Ob-Ra $[16,17]$. Thus, leptin treatment of human granulosa cells over different time intervals was used to monitor the activation of the MAPK pathway. As shown in our results, leptin induced the phosphorylation of ERK1/2 (Figure 3B), p38 (Figure 3C) and JNK (Figure 3D) in a time-dependent manner. To further elucidate the signal- 
A

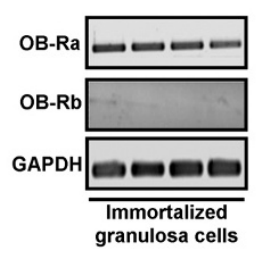

B

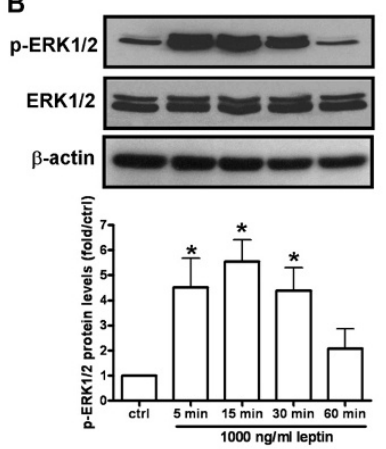

C
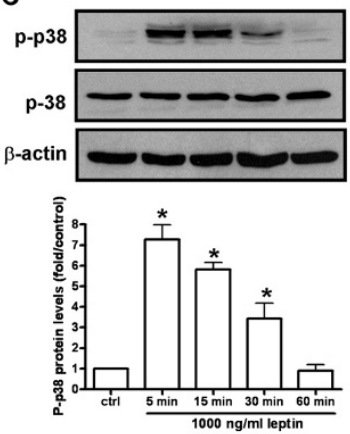

D

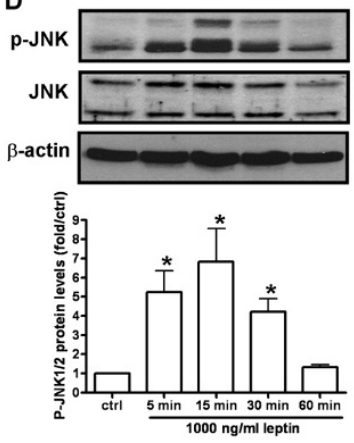

Figure 3

Leptin induced MAPK pathway in human granulosa cells. (A) The expression of leptin receptor in human immortalized granulosa cells were monitored by semi-quantitative RT-PCR. Upper bands showed the expression of short form leptin receptor (Ob-Ra) in 4 different passages of immortalized granulosa cells. Lower band is to detect the expression of long form leptin receptor (Ob-Rb) in immortalized granulosa cells. GAPDH was used as internal standard. Cells were treated with leptin $(1000 \mathrm{ng} / \mathrm{ml})$ for different time scale $(5,15,30,60 \mathrm{~min})$ and cell lysates were collected and subjected to Western blot analysis to monitor the expression of phosphorylated ERKI/2 (B), phosphorylated p38 (C) and phosphorylated JNK (D). Total ERKI/2, p38, JNK and $\beta$-actin were detected as internal standard. Upper bands are Western blotting representative datas from three independent experiments. Lower bars were integrated optical density (IOD) of target phosphorylated protein expression with target total protein normalization. Each data point in the figure represents the mean \pm SD of three independent experiments. * above the bars indicates that those groups differ significantly from untreated control $(P<0.05)$. (ctrl $=$ control).

A
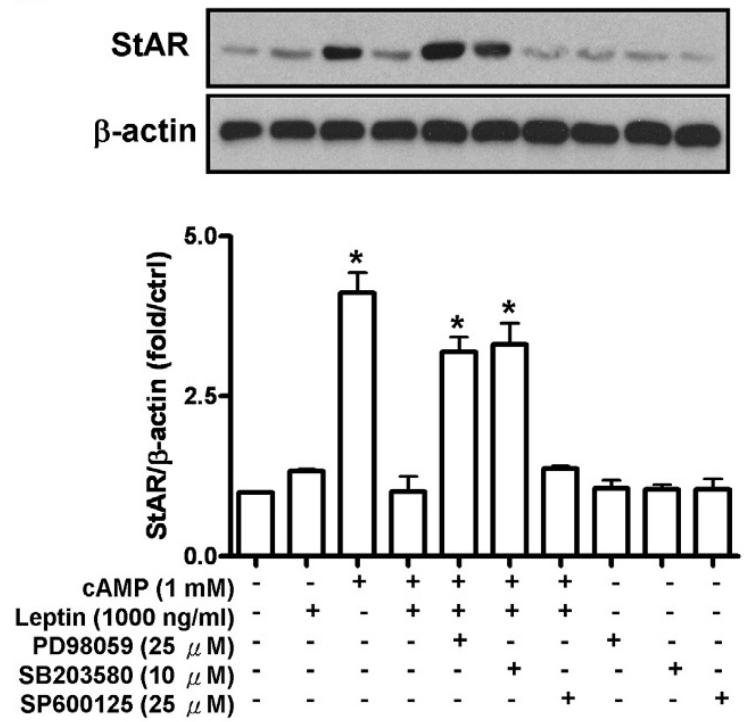

B

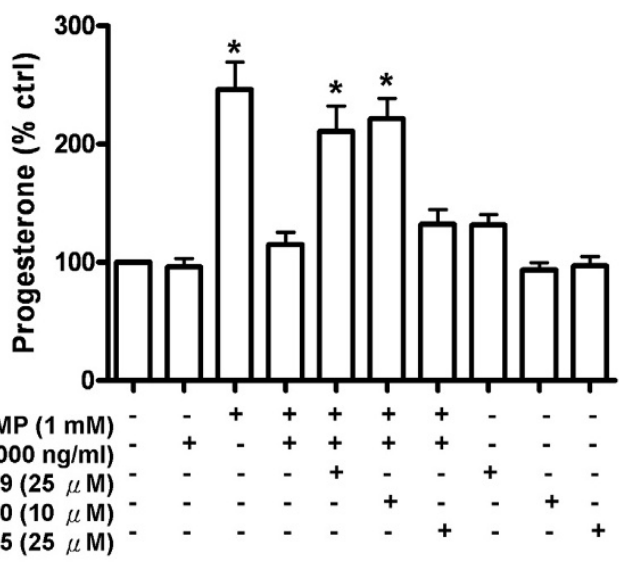

Figure 4

Leptin acted through ERKI/2 and p-38 pathways to modulate steroidogenesis in human granulosa cells. Cells were treated with leptin $(1000 \mathrm{ng} / \mathrm{ml})$ in the presence or absence of ERKI/2 inhibitor (PD98059, $25 \mu \mathrm{M}$ ), p38 inhibitor (SB203580, $10 \mu \mathrm{M}$ ) and JNK inhibitor (SP600I25, $25 \mu \mathrm{M}$ ) for $24 \mathrm{~h}$. Cell lysates were collected and subjected to Western blot analysis to monitor the expression of StAR protein (A) and media were collected and assayed for progesterone production by ELISA (B). Upper bands in (A) are Western blotting representative data from three independent experiments. Lower bars were integrated optical density (IOD) of StAR protein expression with $\beta$-actin normalization. Each data point in (A) represents the mean \pm SD of three independent experiments. Each data point in (B) represents the mean \pm SEM of three independent experiments. * above the bars indicate that those groups differ significantly from untreated control $(P<0.05)$. 
ing pathways involved in the leptin-inhibited steroidogenesis in human granulosa cells, we used pharmacological inhibitors to individually block the ERK1/2, p38 and JNK pathways. The effectiveness of each inhibitor was tested prior to use in the current experiments (data not shown). Results showed that pretreatment for 30 minutes with the ERK1/2 inhibitor PD98059 or the p38 inhibitor SB203580 prior to co-treatment with 8-bromo cAMP and leptin reversed the inhibition of leptin on 8-bromo cAMP-induced StAR protein expression (Figure 4A) and progesterone production (Figure 4B) in granulosa cells. Interestingly, pretreatment with the JNK inhibitor SP600125 did not inhibit the leptin effect. These results suggest that the ERK1/2 and p38 MAPK pathways are necessary for leptin-mediated interference of cAMPstimulated steroidogenesis in human granulosa cells.

\section{Leptin modulates steroidogenesis in human granulosa cells through the short form leptin receptor (OB-Ra)}

To further confirm the role of the leptin receptor in leptinmodulated steroidogenesis in human granulosa cells, we used siRNA technology to knockdown the endogenous expression of the leptin receptor in these cells. The effectiveness of the siRNA was confirmed by Western blot analysis (Figure 5A). Knockdown of the leptin receptor in granulosa cells impaired the ability of leptin to inhibit 8bromo cAMP-stimulated StAR protein expression (Figure $5 \mathrm{~B}$ ) and progesterone production (Figure 5C). These results confirm that leptin acts through its receptor on immortalized human granulosa cells to initiate the MAPK pathway and downregulate the cAMP-induced steroidogenesis.

\section{Discussion}

Compelling evidence demonstrates a direct inhibitory action of leptin on steroid hormone secretion. Such effects have been independently reported by different groups in the three major steroidogenic tissues, namely the adrenal gland, the ovary and the testis [18-22]. However, the mechanisms for such an inhibitory action are only partially characterized, and little attention has been paid to the molecular events involved in leptin-induced inhibition of progesterone secretion in granulosa cells. To gain insight into the mechanisms whereby leptin suppresses progesterone secretion in vitro, we correlated the hormonal secretory responses to mRNA expression levels of StAR, P450scc and 3 3 -HSD in cAMP-stimulated immortalized human granulosa cells after exposure to high dosage of recombinant human leptin. In the present study we demonstrate that the physiological induction of StAR protein by CAMP, a rate-limiting step in steroidogenesis in steroidogenic cells, is significantly reduced by leptin treatment. These results confirm the predominantly inhibitory effects that leptin exerts on progesterone production in human granulosa cells. In addition, it was the first dem- onstration that the leptin short form receptor was involved in leptin-mediated inhibition of cAMP-stimulated steroidogenesis via the activation of the MAPK signaling pathway.

Leptin was shown to be distributed in the intact ovary and have distinct changes in its localization during folliculogenesis [23]. Study suggested that leptin may be produced locally and act in autocrine or paracrine way to affect steroidogenesis in the human ovary [23]. During obesity, both serum and follicular fluid levels of leptin may be as high as $100 \mathrm{ng} / \mathrm{ml}[24,25]$ and our study provides evidence that this high concentration of leptin suppressed the production of progesterone in granulosa cells. More importantly, treatment with a $1000 \mathrm{ng} / \mathrm{ml}$ of high dosage leptin also strikingly inhibited the cAMP-induced steroidogenesis in granulosa cells. This is in agreement with findings in PCOS demonstrating conspicuous occurrence of leptin in the wall of polycystic follicles, higher local concentration of leptin independent of the serum level with hormonal dysregulation in granulosa cells [26] which may account for the decreased pregnancy rate in these PCOS women [10].

Several reports have now demonstrated expression of biologically active isoforms of the leptin receptor in the endocrine pancreas [27], the ovary [8] and the placenta [28]. Consistent with this widespread expression, leptin can directly modulate the activity of these glands. Leptin has been shown to inhibit insulin secretion from pancreatic $\beta$ cells [29]. Leptin decreases the production of estradiol and progesterone from ovarian granulosa cells $[30,31]$, at least partly via inhibition of the electron transport protein adrenodoxin [31]. Finally, leptin can modulate the release of hCG from human trophoblast cells in culture [32]. In our cell model, it was shown that only the leptin short form (Ob-Ra) receptor is expressed in the culture system. Interestingly, using siRNA to knockdown the endogenous leptin receptor reversed the inhibition of leptin on cAMPinduced StAR protein expression and progesterone production. These results suggest that Ob-Ra is functional in our culture system and that this leptin receptor isoform plays a role in the regulation of steroidogenesis in human granulosa cells.

Leptin receptors are structurally similar to the class I cytokine receptor family [33]. In humans, the leptin receptor (OB-R) is produced in several alternatively spliced forms, designated OB-Ra, OB-Rb, OB-Rc, OB-Re [34]. Each of these isoforms has an extracellular domain and a transmembrane domain in common, with a variable intracellular domain that is characteristic for each of the isoforms. Based on the variable intracellular domain the isoforms are classified as short (OB-Ra), long (OB-Rb) and secreted (OB-Re) leptin receptor. Other than the clas- 
A

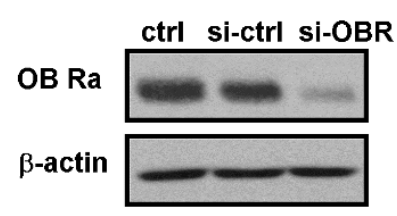

B

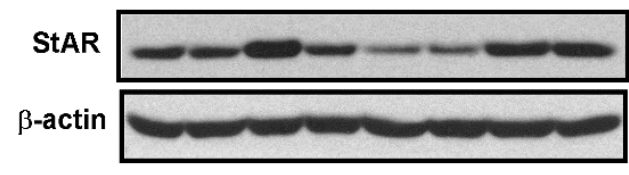

C

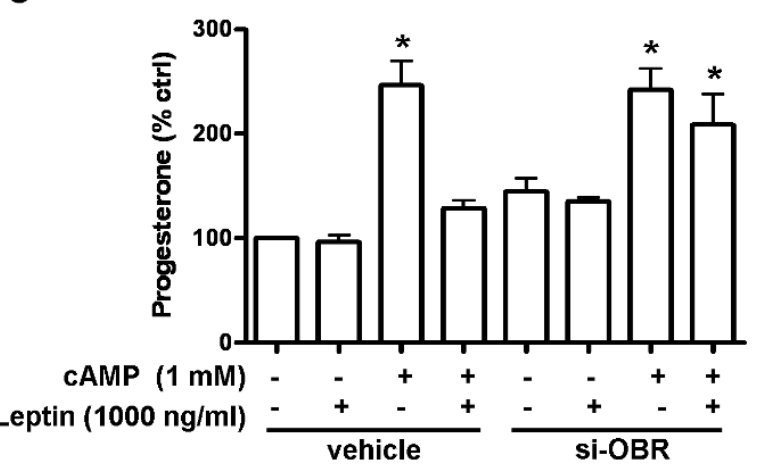

Figure 5

Leptin acted through short form leptin receptor to downregulate the 8-bromo cAMP-stimulated steroidogenesis in human granulosa cells. Cells were transfected with leptin receptor siRNA (si-OBR) for $24 \mathrm{~h}$ to reduce the endogenous expression of leptin receptor in human granulosa cells. Western blot analysis was used to monitor the efficiency of the siRNA (A). Transfected cells were then treated with leptin $(1000 \mathrm{ng} / \mathrm{ml})$ in the presence or absence of 8-bromo cAMP ( $1 \mathrm{mM}$ ) for $24 \mathrm{~h}$ and cell lysates were collected to detect the expressions of StAR protein (B) and media were collected and assayed for progesterone production (C). Blots in (B) are Western blotting representative data from three independent experiments. $\beta$ actin was detected as internal standard. Each data point in (C) represents the mean \pm SEM of three independent experiments. * above the bars indicate that those groups differ significantly from untreated control in either vehicle or si-OBR group respectively $(P<0.05)$.

sical JAK/STAT signaling pathways [35], leptin may act through OB-Ra or OB-Rb to trigger the MAPK cascade in two different ways, i.e. via tyrosine phosphorylation of JAK2 receptor-associated activation or independently of receptor phosphorylaton [17,36]. Although the molecules that are involved in transmitting the leptin signal have not been completely elucidated, activated MEKs (MAPK/ERK kinases) phosphorylate ERKs, leading finally to the expression of specific target genes, such as $c$-fos and egr-1, that participate in cell proliferation and differentiation [37]. The other two members of the MAP kinase family, p38 MAP kinase and NH2-terminal c-Jun kinase/stressactivated protein kinase (JNK) have also been shown to be activated by leptin $[38,39]$.

Many reports have demonstrated the involvement of the MAPK pathway in steroidogenesis in granulosa cells. Activation of the MAPK cascade by gonadotropins mediates down-regulation of steroidogenesis via attenuation of StAR expression [40]. EGF (epidermal growth factor) stimulates steroidogenesis of granulosa cells through activation of the ERK-related MAP kinase pathway [41]. PGF $2 \alpha$ (prostaglandin F2 $\alpha$ )-induced MAPK activation is associated with modulation of progesterone production [42]. In the present study, we demonstrated that leptin is capable of inducing the phosphorylation of ERK, phosphorylation of p38 and phosphorylation of JNK. Interestingly, only the ERK and p38 inhibitors were able to reverse leptin mediated inhibition of StAR protein expression and progesterone production in granulosa cells. This suggests that these two MAPK cascades are involved in leptin mediated inhibition of steroidogenesis in granulosa cells.

\section{Conclusion}

In conclusion, we demonstrate that the StAR protein participates in the physiological inhibition of granulosa cells function by leptin. This leptin-dependent fine tuning of ovarian function could be of clinical relevance in obesity and related disorders as well as in the pathogenesis of infertility.

\section{Competing interests}

The authors declare that they have no competing interests.

\section{Authors' contributions}

QL and SLP designed the study and performed the experiments and participated in discussion of the results and drafted the manuscript. BHY, LC and PCKL were responsible for supervision of this work. PCKL was responsible for the conception, design, discussion of the results, drafting and critical revision of the manuscript. All authors read and approved the final manuscript.

\section{Acknowledgements}

This work was supported by an operating grant from the Canadian Institutes of Health Research (to P.C.K.L.). P.C.K.L. is the recipient of Distinguished Scientist award of the Child \& Family Research Institute. S.L.P. was recipient of Studentship Award from the Interdisciplinary Women's Reproductive Health Research Training Program.

\section{References}

I. McGee EA, Hsueh AJ: Initial and cyclic recruitment of ovarian follicles. Endocr Rev 2000, 2 I (2):200-2I4. 
2. Bluher S, Mantzoros CS: Leptin in reproduction. Curr Opin Endocrinol Diabetes Obes 2007, I4(6):458-464.

3. Mitchell M, Armstrong DT, Robker RL, Norman RJ: Adipokines: implications for female fertility and obesity. Reproduction 2005, I 30(5):583-597.

4. Frisch RE: The right weight: body fat, menarche and ovulation. Baillieres Clin Obstet Gynaecol 1990, 4(3):419-439.

5. Grodstein F, Goldman MB, Cramer DW: Body mass index and ovulatory infertility. Epidemiology 1994, 5(2):247-250.

6. Hartz AJ, Barboriak PN, Wong A, Katayama KP, Rimm AA: The association of obesity with infertility and related menstural abnormalities in women. Int / Obes 1979, 3(I):57-73.

7. Karlsson C, Lindell K, Svensson E, Bergh C, Lind P, Billig H, Carlsson LM, Carlsson B: Expression of functional leptin receptors in the human ovary. J Clin Endocrinol Metab 1997, 82(I 2):4 |44-4I48.

8. Cioffi JA, Van Blerkom J, Antczak M, Shafer A, Wittmer S, Snodgrass HR: The expression of leptin and its receptors in pre-ovulatory human follicles. Mol Hum Reprod 1997, 3(6):467-472.

9. Spicer LJ, Chamberlain CS, Francisco CC: Ovarian action of leptin: effects on insulin-like growth factor-I-stimulated function of granulosa and thecal cells. Endocrine 2000, I 2(I):53-59.

10. Li MG, Ding GL, Chen XJ, Lu XP, Dong LJ, Dong MY, Yang XF, Lu XE, Huang HF: Association of serum and follicular fluid leptin concentrations with granulosa cell phosphorylated signal transducer and activator of transcription 3 expression in fertile patients with polycystic ovarian syndrome. I Clin Endocrinol Metab 2007, 92(I 2):477|-4776.

II. Lie BL, Leung E, Leung PC, Auersperg N: Long-term growth and steroidogenic potential of human granulosa-lutein cells immortalized with SV40 large T antigen. Mol Cell Endocrinol 1996, I 20(2): 169-I76.

12. Devoto L, Vega M, Kohen P, Castro A, Castro O, Christenson LK, Carvallo P, Strauss JF 3rd: Endocrine and paracrine-autocrine regulation of the human corpus luteum during the midluteal phase. J Reprod Fertil Supp/ 2000, 55:13-20.

13. Miller WL: Steroidogenic acute regulatory protein (StAR), a novel mitochondrial cholesterol transporter. Biochim Biophys Acta 2007, I 77 I(6):663-676.

14. Payne AH, Hales DB: Overview of steroidogenic enzymes in the pathway from cholesterol to active steroid hormones. Endocr Rev 2004, 25(6):947-970.

15. Choi JH, Park SH, Leung PC, Choi KC: Expression of leptin receptors and potential effects of leptin on the cell growth and activation of mitogen-activated protein kinases in ovarian cancer cells. J Clin Endocrinol Metab 2005, 90(I):207-2I0.

16. Yamashita T, Murakami T, Otani S, Kuwajima M, Shima K: Leptin receptor signal transduction: OBRa and OBRb of fa type. Biochem Biophys Res Commun I 998, 246(3):752-759.

17. Bjorbaek C, Uotani S, da Silva B, Flier JS: Divergent signaling capacities of the long and short isoforms of the leptin receptor. J Biol Chem 1997, 272(5 I):32686-32695.

18. Spicer LJ, Francisco CC: The adipose obese gene product, leptin: evidence of a direct inhibitory role in ovarian function. Endocrinology 1997, I38(8):3374-3379.

19. Pralong FP, Roduit R, Waeber G, Castillo E, Mosimann F, Thorens B, Gaillard RC: Leptin inhibits directly glucocorticoid secretion by normal human and rat adrenal gland. Endocrinology 1998, I39(10):4264-4268.

20. Caprio M, Isidori AM, Carta AR, Moretti C, Dufau ML, Fabbri A Expression of functional leptin receptors in rodent Leydig cells. Endocrinology 1999, I 140 (I I):4939-4947.

21. Tena-Sempere M, Pinilla L, Gonzalez LC, Dieguez C, Casanueva FF, Aguilar E: Leptin inhibits testosterone secretion from adult rat testis in vitro. J Endocrinol 1999, 16 I(2):21 I-2I8.

22. Zachow RJ, Weitsman SR, Magoffin DA: Leptin impairs the synergistic stimulation by transforming growth factor-beta of follicle-stimulating hormone-dependent aromatase activity and messenger ribonucleic acid expression in rat ovarian granulosa cells. Biol Reprod 1999, 6 I(4): I I04-I I09.

23. Loffler S, Aust G, Kohler U, Spanel-Borowski K: Evidence of leptin expression in normal and polycystic human ovaries. Mol Hum Reprod 200I, 7( I 2): I |43-I |49.

24. Erturk E, Kuru N, Savci V, Tuncel E, Ersoy C, Imamoglu S: Serum leptin levels correlate with obesity parameters but not with hyperinsulinism in women with polycystic ovary syndrome. Fertil Steril 2004, 82(5): I 364-I 368.
25. Liuzzi A, Savia G, Tagliaferri M, Lucantoni R, Berselli ME, Petroni ML, De Medici C, Viberti GC: Serum leptin concentration in moderate and severe obesity: relationship with clinical, anthropometric and metabolic factors. Int I Obes Relat Metab Disord 1999, 23(10): 1066-1073.

26. Erickson GF, Magoffin DA, Garzo VG, Cheung AP, Chang RJ: Granulosa cells of polycystic ovaries: are they normal or abnormal? Hum Reprod 1992, 7(3):293-299.

27. Kieffer TJ, Heller RS, Habener JF: Leptin receptors expressed on pancreatic beta-cells. Biochem Biophys Res Commun 1996, 224(2):522-527.

28. Masuzaki $\mathrm{H}$ Ogawa $\mathrm{Y}$, Sagawa $\mathrm{N}$, Hosoda $\mathrm{K}$, Matsumoto $\mathrm{T}$, Mise $\mathrm{H}$, Nishimura H, Yoshimasa Y, Tanaka I, Mori T, Nakao K: Nonadipose tissue production of leptin: leptin as a novel placenta-derived hormone in humans. Nat Med 1997, 3(9): 1029-1033.

29. Roduit R, Thorens B: Inhibition of glucose-induced insulin secretion by long-term preexposure of pancreatic islets to leptin. FEBS Lett 1997, 415(2): I79-182.

30. Zachow RJ, Magoffin DA: Direct intraovarian effects of leptin: impairment of the synergistic action of insulin-like growth factor-I on follicle-stimulating hormone-dependent estradiol- 17 beta production by rat ovarian granulosa cells. Endocrinology 1997, I 38(2):847-850.

31. Barkan D, Jia H, Dantes A, Vardimon L, Amsterdam A, Rubinstein M: Leptin modulates the glucocorticoid-induced ovarian steroidogenesis. Endocrinology 1999, |40(4): |73|-|738.

32. Chardonnens D, Cameo P, Aubert ML, Pralong FP, Islami D, Campana A, Gaillard RC, Bischof P: Modulation of human cytotrophoblastic leptin secretion by interleukin- I alpha and I 7 beta-oestradiol and its effect on HCG secretion. Mol Hum Reprod 1999, 5(I I): 1077-1082.

33. Tartaglia LA: The leptin receptor. I Biol Chem 1997, 272(10):6093-6096.

34. Tartaglia LA, Dembski M, Weng X, Deng N, Culpepper J, Devos R, Richards G], Campfield LA, Clark FT, Deeds J, Muir C, Sanker S, Moriarty A, Moore KJ, Smutko JS, Mays GG, Wool EA, Monroe CA, Tepper RI: Identification and expression cloning of a leptin receptor, OB-R. Cell 1995, 83(7):|263-I27|.

35. Fruhbeck $G$ : Intracellular signalling pathways activated by leptin. Biochem / 2006, 393(Pt I):7-20.

36. Hegyi K, Fulop K, Kovacs K, Toth S, Falus A: Leptin-induced signal transduction pathways. Cell Biol Int 2004, 28(3):159-169.

37. Morton NM, Emilsson V, Liu YL, Cawthorne MA: Leptin action in intestinal cells. J Biol Chem I998, 273(40):26I 94-2620I.

38. Brink GR van den, O'Toole T, Hardwick JC, Boogaardt DE van den, Versteeg HH, van Deventer SJ, Peppelenbosch MP: Leptin signaling in human peripheral blood mononuclear cells, activation of p38 and p42/44 mitogen-activated protein (MAP) kinase and p70 66 kinase. Mol Cell Biol Res Commun 2000, 4(3): I 44-I50.

39. Davis RJ: Signal transduction by the JNK group of MAP kinases. Cell 2000, I03(2):239-252.

40. Tajima K, Dantes A, Yao Z, Sorokina K, Kotsuji F, Seger R, Amster$\operatorname{dam} A$ : Down-regulation of steroidogenic response to gonadotropins in human and rat preovulatory granulosa cells involves mitogen-activated protein kinase activation and modulation of DAX-I and steroidogenic factor-I. I Clin Endocrinol Metab 2003, 88(5):2288-2299.

4I. Makarevich AV, Sirotkin AV, Chrenek P, Bulla J: Effect of epidermal growth factor (EGF) on steroid and cyclic nucleotide secretion, proliferation and ERK-related MAP-kinase in cultured rabbit granulosa cells. Exp Clin Endocrinol Diabetes 2002, I I0(3): 124-129.

42. Tai CJ, Kang SK, Choi KC, Tzeng CR, Leung PC: Role of mitogenactivated protein kinase in prostaglandin $\mathrm{f}(2 \mathrm{alpha})$ action in human granulosa-luteal cells. J Clin Endocrinol Metab 200I, 86(I):375-380. 